\title{
Short-term monitoring of rangeland forage conditions with AVHRR imagery
}

\author{
DAVID P. THOMA, DEREK W. BAILEY, DANIEL S. LONG, GERALD A. NIELSEN, MARI P. HENRY, MEAGAN \\ C. BRENEMAN, AND CLIFFORD MONTAGNE
}

Authors are Research Assistant, Department of Soil, Water and Climate, University of Minnesota, St Paul, Minn.; assistant professors (Bailey and Long), Northern Agricultural Research Center, Montana State University, Havre, Mont.; professors (Nielsen and Montagne) and research assistants (Henry and Breneman), Department of Land Resources and Environmental Sciences, Montana State University, Bozeman, Mont.

Abstract

A study was conducted to determine the potential of using Advanced Very High Resolution Radiometer (AVHRR) imagery to monitor short-term changes in rangeland forage conditions on a regional scale. Forage biomass and nitrogen concentration were estimated at 6 study sites throughout a typical grazing season (April to October). Study sites were located in northern and southern Montana in areas classified as foothills grassland and shortgrass prairie. Normalized Difference Vegetation Index (NDVI) values from AVHRR imagery (1 km pixels) were used to predict live biomass, dead standing biomass, total biomass, nitrogen $(\mathrm{N})$ concentration and standing $\mathbf{N}$. Values of the NDVI were correlated $(r>0.4, P<0.01)$ to live, dead, and total biomass estimates and standing $N$, but were not correlated to $N$ concentration $(r=0.04, P=0.8)$. Relationships between NDVI and vegetative attributes were similar $(P>0.05)$ for all 6 study sites, which indicates that NDVI could be used to predict forage abundance at multiple locations and at variable dates. Using simple linear regression, NDVI accounted for $63 \%$ of the variation in live and total biomass, $18 \%$ of the variation in dead biomass, $66 \%$ of the variation in standing $N$, but $<1 \%$ of the variation in $N$ concentration. The NDVI obtained from AVHRR imagery was a good predictor of forage abundance as measured by live, dead and total biomass as well as standing $\mathrm{N}$, but it was not related to forage quality as measured by $\mathrm{N}$ or crude protein concentration. On a regional basis, land managers could use AVHRR-NDVI values to identify areas with high or low levels of forage abundance that may result from factors such as drought, variable precipitation patterns, or uneven grazing.

Key Words: NDVI, biomass, nitrogen, regional

Forage quantity and quality are major determinants of carrying capacity and performance of grazing animals (Valentine 1990). Ground-based methods are not practical for assessing forage quality and quantity over extensive geographic areas. Remote

Research was funded by the Upper Midwest Aerospace Consortium, Montana Space Grant, Montana State University Mountain Research Center, Montana State University Department of Land Resources and Environmental Sciences and the Montana Agricultural Experiment Station. This manuscript has been assigned Journal Series No. 2000-80, Montana Agricultural Experiment Station, Montana State University, Bozeman.

Manuscript accepted 20 Oct. 01.

\section{Resumen}

Se condujo un estudio para determinar el potencial de utilizar las imágenes de Radiometría Avanzada de Muy Alta Resolución (RAMAR) para monitorear los cambios a corto plazo en las condiciones de forraje del pastizal a escala regional. La biomasa de forraje y las concentraciones de nitrógeno fueron estimadas en 6 sitios de estudio a lo largo de una estación típica de apacentamiento. (Abril a Octubre). Los sitios de estudio estuvieron localizados en el norte y sur de Montana, en áreas clasificadas como pastizales de pie de montaña y pastizales cortos. Los valores del Indice de Diferencias Normalizadas de Vegetación (IDNV) obtenidos a partir de imágenes de RAMAR (pixeles de 1 km) se usaron para predecir la biomasa viva, la biomasa muerta en pie, la biomasa total la concentración de nitrógeno $(\mathrm{N})$ y el $\mathrm{N}$ en pie. Los valores de IDNV se correlacionaron $(\mathrm{r}>0.4, \mathrm{P}<$ 0.01) con las estimaciones de biomasa viva, muerta $y$ total y el $\mathrm{N}$ en pie, pero se correlacionaron con la concentración de $\mathbf{N}(r=$ $0.04, P=0.8$ ). Las relaciones entre IDNV y los atributos vegetativos fueron similares $(P>0.05)$ para los 6 sitios de estudio, lo cual indica que los IDNV pudieran ser usados para predecir la abundancia de forraje en múltiples localidades y en fechas variables. Con regresión lineal simple, el IDNV explicó el 63\% de la variación de la biomasa viva y total, el $18 \%$ de la variación de la biomasa muerta, el $66 \%$ de la variación del $\mathrm{N}$ en pie, pero explicó menos del $1 \%$ de la variación en la concentración de $\mathbf{N}$. EI IDNV obtenido a partir de imágenes de RAMAR fue bueno para predecir la abundancia de forraje medido como la biomasa viva, muerta y total, así como por el $\mathbf{N}$ en pie, pero no estuvo relacionado a la calidad del forraje medida como la concentración de $\mathbf{N}$ o proteína cruda. En base regional, los manejadores de tierras pudieran usar los valores de RAMAR-IDNV para identificar áreas con niveles altos o bajos de abundancia de forraje que pueden resultar de factores tales como sequía, patrones variables de precipitación y apacentamiento desigual.

sensing research has demonstrated, however, that quantity of green vegetation may be estimated using vegetation indices derived from multispectral, aerospace imagery (Tueller 1989 , Wessman et al. 1995). Vegetation indices, which contrast the high chlorophyll absorption region in the red vs. the high reflectivity in the near infrared, are assumed to indicate plant photosynthetic activity and aboveground primary production (Tucker 1979, Wiegand and Richardson 1990). Frequently, red and infrared image bands are used to compute a Normalized 
Difference Vegetation Index (NDVI), defined as the ratio of the difference between near-infrared and red wavelengths to the sum of the 2 (Colwell 1974, Tucker et al. 1983, Justice and Hiernaux 1986).

One of the most commonly encountered NDVI image products is that provided by the NOAA Advanced Very High Resolution Radiometer (AVHRR) (Gutman 1991). The NDVI has been widely investigated for use in predicting the amount of vegetative biomass in rangeland. For example, Merrill et al. (1993) derived a vegetation index from Landsat multispectral scanner data for use as an auxiliary variable for a linear regression model to predict green herbaceous phytomass on rangeland in Yellowstone National Park. Tucker and Vanparet (1985) found a linear relationship between AVHRR-NDVI and end of season dry biomass of grassland in the African Sahel. Kennedy (1989) discovered that AVHRR-NDVI was strongly correlated with biomass and cover of range vegetation over a wide range of soil and topographic conditions in Tunisia.

Land managers, livestock producers, animal feed suppliers, and others are often interested in both forage quantity and quality. For example, a combination of forage quantity and quality attributes (standing nitrogen, $\mathrm{kg} \mathrm{N} \mathrm{ha}^{-1}$ ) was a good predictor of where cattle preferred to graze (Senft et al. 1985). Handheld radiometers have been used to estimate nitrogen concentration of plant tissue (Tucker 1979 , Plummer 1988). Researchers have not, however, examined the potential of AVHRR for assessing the quality of range forage. The purpose of this study was to investigate relationships between AVHRR-NDVI and measures of forage quality, and describe linear regression models for predicting both quantity and quality of forage in Montana rangelands.

\section{Materials and Methods}

\section{Study Areas}

Six study areas were established in 1997 on grasslands in southern and northern Montana. Grasslands were classified into 2 types: shortgrass prairie and foothill grassland, based on dominant vegetation (Mueggler and Stewart 1980). Selection of study sites in these 2 types of rangeland ensured that relationships between normalized difference vegetation index
(NDVI) and forage characteristics could be evaluated in a wide range of conditions during the summer grazing season.

Three of the study areas were established on foothill grassland: 1) $10 \mathrm{~km}$ east of Livingston, Mont. ( $45^{\circ} 41^{\prime} 48^{\prime \prime} \mathrm{N} 110^{\circ}$ 26' 05" W), 2) $20 \mathrm{~km}$ south of Havre, Mont. (Thackeray Ranch, $48^{\circ} 21^{\prime} 50^{\prime \prime} \mathrm{N}$ $109^{\circ} 35^{\prime} 00^{\prime \prime} \mathrm{W}$ ), and 3) $30 \mathrm{~km}$ southwest of Chinook, Mont. (Ross Ranch, $48^{\circ} 15^{\prime}$ $\left.46^{\prime \prime} \mathrm{N} 109^{\circ} 28^{\prime} 29^{\prime \prime} \mathrm{W}\right)$. Average annual precipitation for these 3 areas varies from 350 to $450 \mathrm{~mm}$ (Caprio et al. 1994). Dominant species includes rough fescue (Festuca scabrella Torr.), bluebunch wheatgrass (Pseudoroegneria spicatum (Pursh) A. Löve), western wheatgrass (Pascopyrum smithii (Rydberg) Löve), Idaho fescue (Festuca idahoensis Elmer), and bluegrass (Poa spp.). Hilltops are forested with Douglas fir (Pseudotsuga menziesii var. glauca (Bessin.) Franco) or ponderosa pine (Pinus ponderosa Dougl.). Vegetation along drainage bottoms includes chokecherry (Prunus virginiana L.), western snowberry (Symphoricarpos occidentalis Hook), and quaking aspen (Populus tremuloides Michx.) (Mueggler and Stewart 1980).

The 3 remaining study areas were established in shortgrass prairie: 1) $5 \mathrm{~km}$ west of Gardiner, Mont. (45 $01^{\prime} 21^{\prime \prime} \mathrm{N} 110^{\circ} 41^{\prime}$ 28" W), 2) $30 \mathrm{~km}$ northwest of Chinook, Mont. (48 42' 37' N $109^{\circ} 29^{\prime} 07^{\prime \prime} \mathrm{W}$ ), and 3) $10 \mathrm{~km}$ north of Zurich, Mont. ( $48^{\circ} 36^{\prime}$ $\left.33^{\prime \prime} \mathrm{N} 108^{\circ} 57^{\prime} 26^{\prime \prime} \mathrm{W}\right)$. These sites near Chinook and Zurich are characterized by terraces and glacial till plains with intermittent, dendritic drainages. Average annual precipitation is 250 to $300 \mathrm{~mm}$ (Caprio et al. 1994). Dominant species includes blue grama (Bouteloua gracilis (H.B.K.) Griffiths), western wheatgrass, and needle-and-thread (Stipa comata Trin. \& Rup.). Other grasses include Sandberg bluegrass (Poa sandbergii Vasey), and upland sedges (Carex spp.) (Mueggler and Stewart, 1980).

The pixel size of the advanced very high resolution radiometer (AVHRR) is $1 \times 1$ $\mathrm{km}$, but the potential error in registration between successive image scenes is up to 2 to 3 pixels. Usually the error is less than 1 pixel. The AVHRR image-to-image registration using automated correlation techniques improves geometric accuracy (root mean square less than 1 pixel) as compared to traditional image-to-map procedures (Eidenshink 1992). To enhance accuracy in the NDVI calibration effort, all study areas were situated within zones that comprised relatively homogenous vegetation. All study areas comprised 9 $\mathrm{km}^{2}$ ( $3 \times 3$ pixels of AVHRR) except for the site near Gardiner that measured only $1 \mathrm{~km}^{2}$ (1 pixel of AVHRR) Boundaries of this study area were specifically placed so that the center of the AVHRR pixel was in the geometric center of the site. The extent of homogeneous vegetation was not as extensive at the Gardiner location.

\section{Ground Sampling}

Mean standing crop of live and dead vegetation (live and dead biomass) and mean $\mathrm{N}$ concentration were estimated in early April and on a bi-weekly basis from May to October at the Gardiner and Livingston study areas. These vegetation attributes were estimated once per month from May to August at the other 4 study sites.

To maximize sampling efficiency, each study area was divided into smaller, relatively homogenous map units using a stratified sampling approach (Tucker et al. 1983, Townshend and Justice 1986, Tappan et al. 1992). Map units were delineated on 1:24,000 orthophotographs and topographic maps based on spatial patterns in vegetation, landform, and land use. At least 2 plots $\left(0.5 \mathrm{~m}^{2}\right)$ were randomly placed within a mapping unit. Study areas included at least 4 sampling units, and measurements were obtained from a total of 20 to 40 plots within each study area during each sampling period. Plots were clipped to ground level and clippings were separated in the field into standing live and dead plant tissue. Clipped plant parts that were green along $\geq 50 \%$ of their length were bagged as live material. Parts with $<50 \%$ green along their length were separated as dead material. Separations of plant material were made without regard to the identity of plant species because the spatial resolution of AVHRR imagery was too coarse for species level detail (Merrill et al. 1993, Kremer and Running 1993).

Clipped plant material was oven-dried at $50^{\circ} \mathrm{C}$ for 48 hours (Richardson et al.1983, Richardson and Everitt 1992). Total biomass was computed as the sum of the live and dead biomass after oven drying. Percent nitrogen by dry weight was determined on ignition with a LECO FP-328 combustion furnace (LECO Corp., St. Joseph, Mich.).

Live standing $\mathrm{N}$ was computed as the dry weight of live biomass multiplied by percent $\mathrm{N}$ in live biomass (Senft et al. 

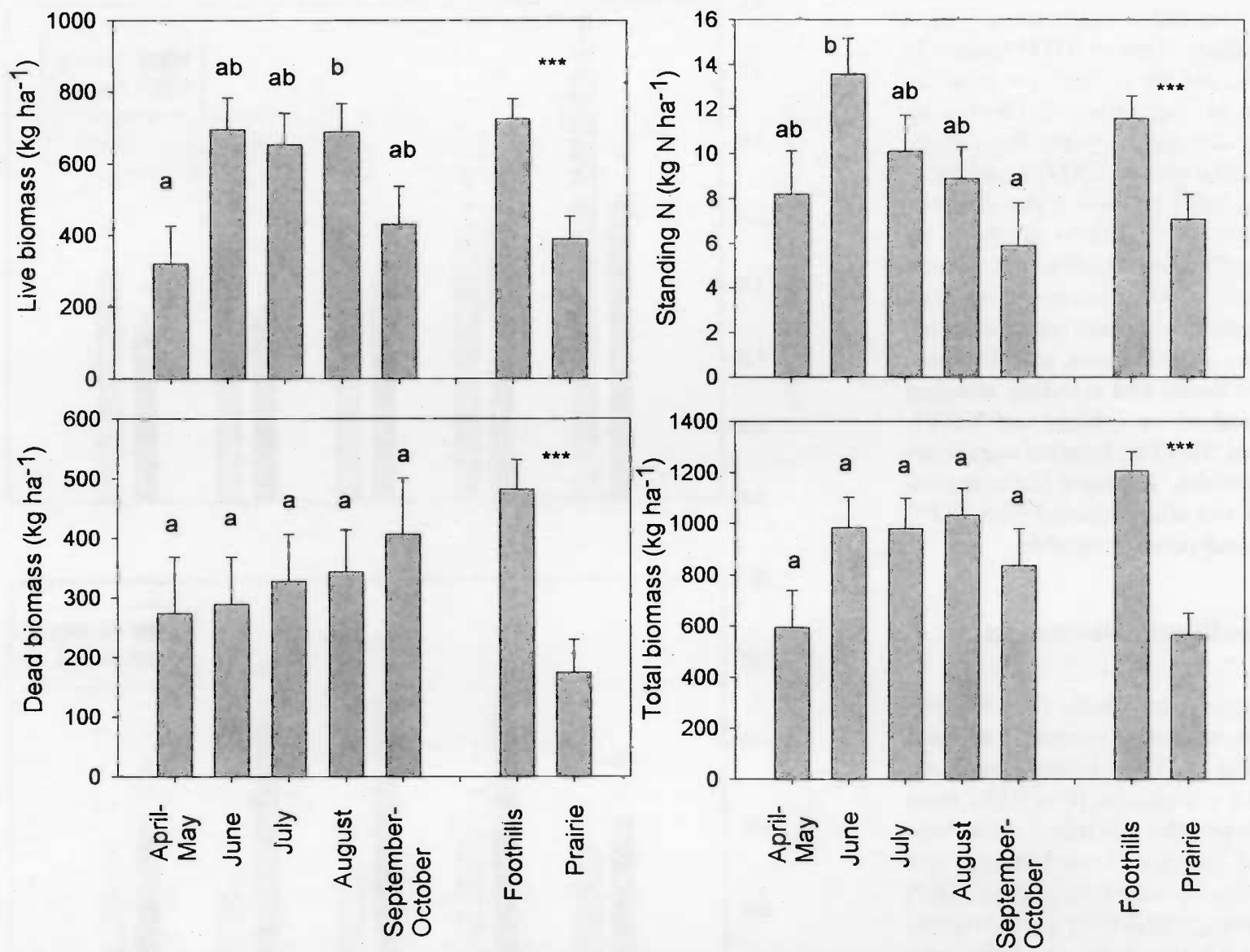

Fig. 1. Mean values of live biomass, dead biomass, total biomass and standing nitrogen for April or May, June, July, August, and September or October during the 1997 growing season $(n=33)$. Mean values of these dependent variables are also presented for foothills grassland and shortgrass prairie sites. Standard errors are presented for each mean. Monthly means without common superscripts differ $(P<0.05)$. Means for foothill grassland and shortgrass prairie sites differ if superscripts are presented $(* *=\mathbf{P}<0.01, * * *=\mathbf{P}<0.001)$.

1985). Mean values of the biomass (live, dead, and total), $\mathrm{N}$ concentration of live biomass and standing $\mathrm{N}$ were determined for each sampling event within each map unit. These mean values were then spatially weighted by the percentage of the study area comprised by each map unit. Mean biomass, standing $\mathrm{N}$ and $\mathrm{N}$ concentration for study area during a given sampling period were calculated from the spatially weighted means for each map unit.

\section{Regression Model for Estimating Forage Quantity and Quality}

Maximum value composite AVHRRNDVI images were obtained from the USGS EROS Data Center in Sioux Falls, S. Dak. Maximum value composite imagery is based on the maximum NDVI value for each pixel of imageries acquired daily over a 2 -week period (Holben 1986) and is used to compensate for variable atmosphere conditions. Raw NDVI values can vary from -1.0 to 1 , and in this study NDVI values for each pixel were scaled so that the range was 0 to 200 using the following equation.

$$
\mathrm{NDVI}=\left(\mathrm{NDVI}_{\mathrm{raw}}+1\right) * 100
$$

In addition, imagery is geometrically registered to a common map projection to enable image-to-image registration. Thus, land managers, who are mainly interested in the data for vegetation assessment and monitoring, are freed from preprocessing the raw data.

Live biomass, dead biomass, total biomass, nitrogen concentration, standing nitrogen, and NDVI estimates from on the ground measurements at each site were evaluated using a model that contained site type (foothill or prairie), month (April-May, June, July, August, and September-October) and the site type by month interaction (SAS 1985). Measurements collected during April and May were pooled together because there were fewer measurements collected in these months and they represented similar forage conditions typical of spring conditions. Similarly, those collected in September and October were pooled together and represented conditions often observed in autumn. Tukey's studentized range test was used for mean separation (Steel and Torrie 1980). We computed the arithmetic mean from the NDVI values from the 9 pixels comprising the study areas $\left(9 \mathrm{~km}^{2}\right)$ and considered it representative of the real NDVI value for each study site. The value of a single pixel was used for the study area near Livingston that measured $1 \mathrm{~km}^{2}$.

Estimates of biomass and $\mathrm{N}$ content that were then were regressed on NDVI values. Because the study areas were expected to differ in terms of vegetation and climate, location was evaluated as a fixed effect in PROC GLM of SAS (SAS 1985). This 
variable was used to test if the absolute values in vegetation parameters varied among locations at given NDVI values. In other words, did the $y$-intercepts from the regression of vegetation attributes on NDVI vary among locations? In addition, the interaction between NDVI and location was included as a test if the slopes of the regression of vegetation attributes on NDVI varied among locations (Timm and Mieczkowski 1997). Therefore, we constructed a predictive model where standing live biomass, dead biomass, total biomass, $\% \mathrm{~N}$ of live tissue and standing nitrogen were dependent variables, and NDVI, location, and NDVI by location were independent variables. A simple linear regression model was also evaluated with NDVI as the only independent variable.

\section{Results and Discussion}

Live biomass was greater $(\mathrm{P}<0.05)$ in August than when first measured in April and May (Fig. 1). Dead biomass and total biomass did not change $(P>0.05)$ from April to September-October. Live biomass, dead biomass, total biomass and standing nitrogen were greater $(\mathrm{P}<0.001)$ on foothill grassland than on shortgrass prairie (Fig. 1). This difference in biomass was likely the result of site differences in precipitation. Foothills grassland typically receives 100 to $250 \mathrm{~mm}$ more rainfall than shortgrass prairie. Live biomass in June was greater $(\mathrm{P}<0.05)$ than during August. Standing nitrogen in June was greater $(\mathrm{P}=$ 0.05) than during September-October. The interaction between site type and month of collection was not important $(P>0.1)$ for live biomass, dead biomass, total biomass, and standing nitrogen. However, there was an interaction between site type and month of collection for plant nitrogen concentration $(P=0.003)$ and NDVI $(P=0.04)$, and monthly means from each site type were evaluated separately. For foothill grassland sites, nitrogen concentration in April-May was greater $(\mathrm{P}<0.05)$ than measurements collected in July, August, and September-October (Fig. 2). Nitrogen concentration in June was greater $(\mathrm{P}<$ 0.05 ) than measurements collected in August and September-October. For shortgrass prairie, plant nitrogen concentration was greater $(\mathrm{P}<0.05)$ in April-May than other months. For foothill grassland, NDVI was greater $(\mathrm{P}<0.05)$ in June than in September-October (Fig. 2). For shortgrass
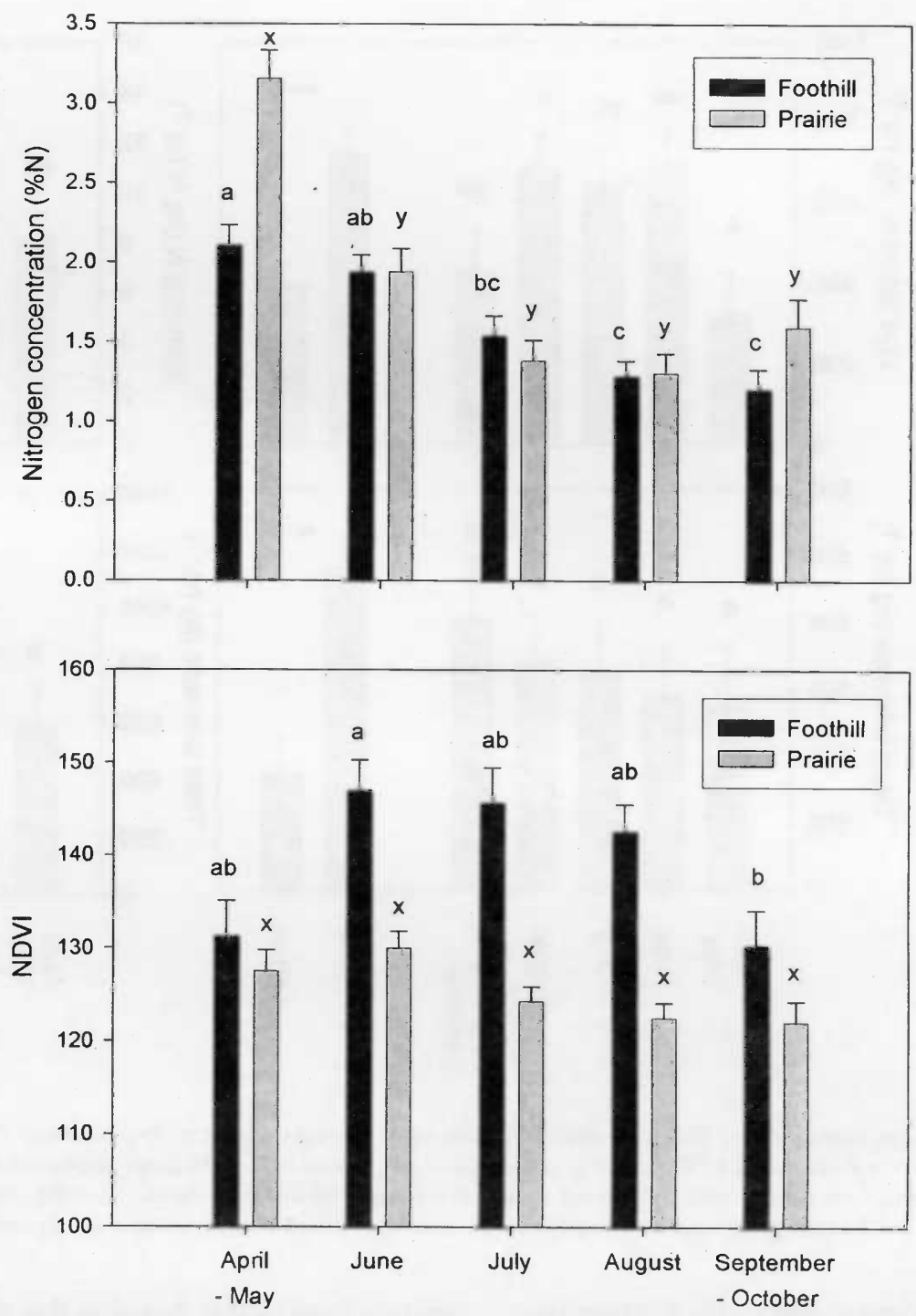

Fig. 2. Mean values of nitrogen concentration and NDVI for April or May, June, July, August and September or October for foothill grassland and shortgrass prairie sites during the 1997 growing season $(n=33)$. Standard errors are presented for each mean. There was an interaction $(P<0.05)$ between month of measurement and site type, and comparisons of monthly means were separately made for each site type. Monthly means from foothill grassland (black bars) without common superseripts $(\mathrm{a}, \mathrm{b}, \mathrm{c})$ differ $(\mathbf{P}<0.05)$. Monthly means from shortgrass prairie sites (gray bars) without common superscripts $(x, y)$ differ $(\mathbf{P}<0.05)$.

prairie, NDVI tended $(\mathrm{P}=0.06)$ to vary among months. Changes in NDVI more closely followed the patterns observed in live biomass and standing nitrogen, which combines both live biomass and nitrogen concentration. We anticipated that NDVI would be associated with live biomass and standing nitrogen because greenness of plant foliage has been found to be highly representative of photosynthetic capacity and efficiency (Richardson et al. 1983, Tucker et al. 1983, Plummer 1988, Benedetti and Rossini 1993).

Effects of location and the interaction between NDVI and locations were not significant $(P>0.05)$ in the initial regression model for all dependent variables. Consequently, data were pooled, and a simple linear regression model containing only NDVI was used to analyze the data. As in this study, Wylie et al. (1995) used a single relationship between AVHRRNDVI and biomass to assign pastoral zones of Niger into 3 classes of rangeland.

In simple linear regression models, NDVI explained $63 \%$ of the statistical variation in both total and live biomass, $18 \%$ in dead biomass, and $66 \%$ in stand- 

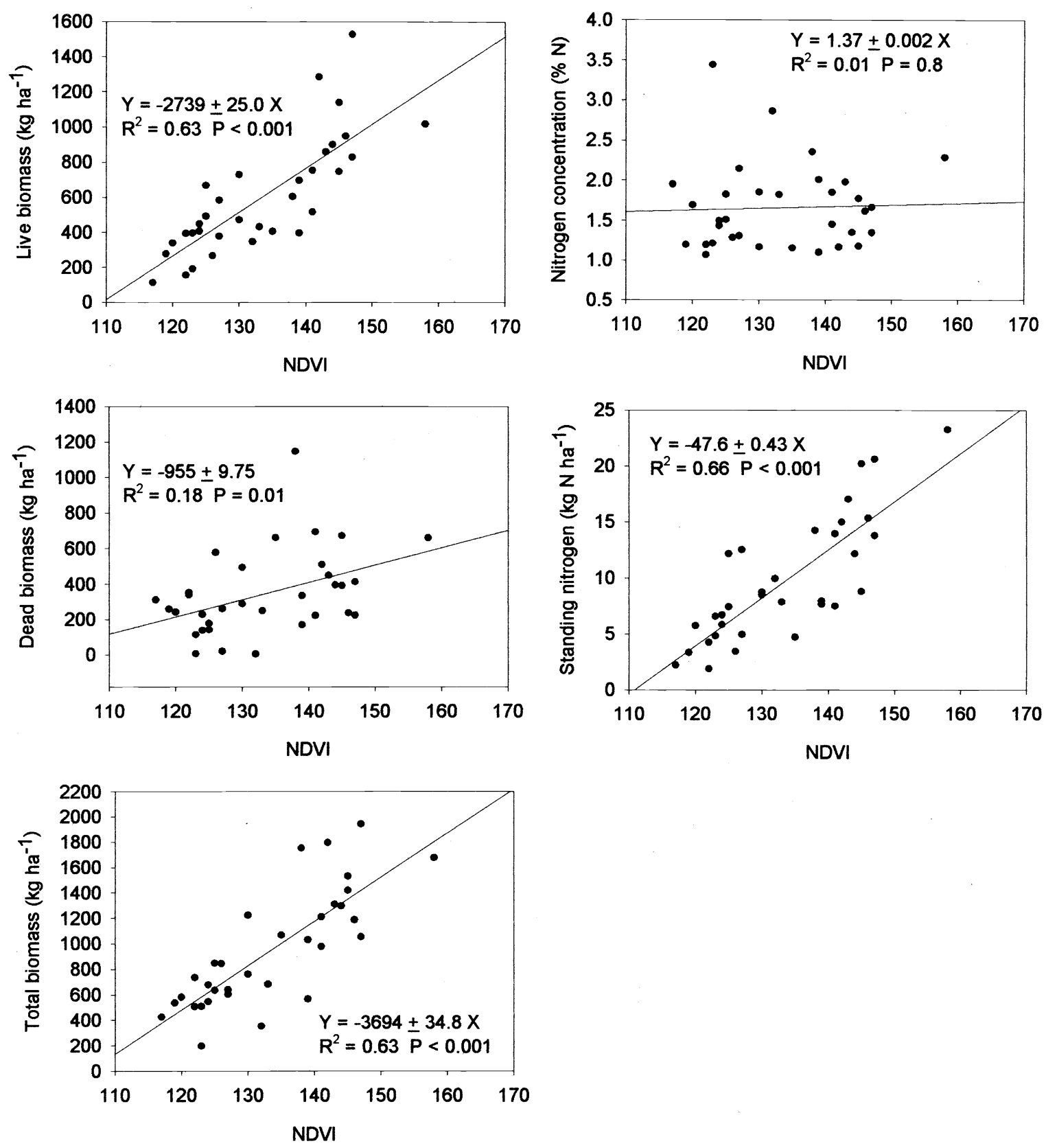

Fig. 3. Scatter plots of live, dead and total biomass, nitrogen concentration and standing nitrogen versus NDVI values from AVHRR imagery. Simple regression lines of dependent variables (live biomass, dead biomass, total biomass, nitrogen concentration and standing nitrogen) on NDVI are also presented.

ing N (Fig. 3). Poor correlation between NDVI and dead biomass was not surprising given the sensitivity of this spectral index for green foliage. Wylie et al. (1995) reported that NDVI accounted for 67 to $80 \%$ of the variation in biomass in 3 of 4 years of their study in Niger. Plant nitrogen concentration was not related $(\mathrm{P}=$ 0.8 ) to NDVI (Fig 3). Differences in NDVI resulting from variable biomass levels across sites and sampling times may have overwhelmed any effects of nitrogen concentration on NDVI.

When the simple linear regression was restricted to the period when range vegetation reached peak growth (1 June to 15 July), model results improved slightly. For live biomass, the $y$-intercept was $-1475 \pm$ 537 , and the slope was $15.9 \pm 3.9\left(\mathrm{R}^{2}=\right.$ $0.71, \mathrm{P}=0.005)$ as compared to $-2739+$
463 and $25.0 \pm 3.5$, respectively, for the entire data set (Fig. 3). For total biomass, the $y$-intercept for peak growth was -2896 \pm 717 and the slope was $28.1 \pm 5.2\left(\mathrm{R}^{2}=\right.$ $0.81, \mathrm{P}=0.001)$ as compared to $-3694 \pm$ 635 and $34.8 \pm 4.8$, respectively, for the entire data set (Fig. 3). This improvement is probably due to radiometric dominance of live vegetation, which tends to be stronger than that of soil background and 
dead biomass in that time of year. These results suggest that peak growth (June and early July in our study) is a good time period to use NDVI to predict and compare total annual vegetative growth within a region.

In this study, relationships between NDVI and standing live biomass or standing $\mathrm{N}$ were based on model calibration at 6 study sites with ground data collected throughout the growing season. These models may need to be calibrated periodically to account for variation in local climate and range vegetation phenology. However, any adjustments should be small because regression coefficients (intercept and slope of live, dead or total biomass and standing nitrogen on NDVI) from the limited peak growth period (June and early July) in this study were similar in order of magnitude to those obtained from the entire data, and the relationship between the dependent vegetative variables and NDVI did not vary among site types. The interaction between site types and NDVI was not significant in this study. In addition, the relationship between total biomass and NDVI observed by Kennedy (1989) in Tunisia was similar to observed in Montana for standing crops up to $2500 \mathrm{~kg}$ $\mathrm{ha}^{-1}$ when similar regression models were applied. Intercepts were $-3741 \pm 1220$ and $-3693 \pm 695$ and slopes were $43.5 \pm 11.6$ and $34.8 \pm 4.8$ in the Tunisia and Montana studies, respectively. Confidence intervals (95\%) of regression coefficients between NDVI and total biomass overlapped in all but 1 year of a 5-year study conducted by Wylie et al. (1992).

Relationships between forage characteristics and NDVI were linear over a relatively wide range of vegetative productivity levels (300 to $1300 \mathrm{~kg} \mathrm{ha}^{-1}$ in mean live biomass) within the 2 major grassland community types studied. If live biomass falls below $250 \mathrm{~kg} \mathrm{ha}^{-1}$, spectral responses of bare soil and dead biomass may dominate and result in underestimation of live biomass (Tucker and Vanparet 1985). If biomass levels are high and plant canopy is relatively closed, live biomass may be overestimated, plant canopy closure is high (Carneggie et al. 1983, Box et al. 1989). Therefore, the model should not be used to extend predictions beyond the range of original data that were used to establish a linear relationship. Other factors that negatively influence NDVI-vegetation relationships include atmospheric attenuation, topographic complexity, and pixel misregistration in successive imagery (Smith et al. 1997).

Image processing and the use of NDVI rather than absolute reflectance values reduces the chance that temporal variation in atmospheric conditions could result in the presumption of a change in forage conditions when in fact none occurred (Eidenshink 1992). Using the maximum NDVI value during a 2 -week interval theoretically reduces the effects of cloud-contaminated pixels and theoretically reduces the effects of atmospheric conditions associated with changes in nadir viewing angles (Holben 1986). Temporal variability in reflectance is also accounted for in the NDVI value because it is based on the relative difference in the reflectance of red and infrared wavelengths rather than the absolute values (Colwell 1974, Tucker et al. 1983).

The importance of AVHRR-NDVI lies in its ability to provide the temporal resolution needed for frequent monitoring of changes in the quality of green vegetation. By exploiting relationships between the NDVI and live biomass or standing N, land managers may be able to predict when and where shortfalls in higher quality vegetation may occur within extensive management units. Furthermore, the predictive ability of standing $\mathrm{N}$ by AVHRR data may allow managers to predict where livestock may graze. Senft et al. (1985) reported that cattle grazed in areas with greater standing $\mathrm{N}$. Cattle grazing was associated significantly more with standing $\mathrm{N}$ than with biomass or $\mathrm{N}$ concentration.

We conclude that maximum value composite AVHRR-NDVI imagery could produce reasonable estimates of live biomass and standing $\mathrm{N}$ at regional scales, when calibrated on ground data from 6 study sites within foothills grassland and shortgrass prairie areas of Montana. These results provided estimates of total forage quantity and more importantly the quantity of higher quality forage (live biomass and standing $\mathrm{N}$ ) that would otherwise have been time consuming to obtain with conventional ground surveys alone. However, AVHRR-NDVI was not a good predictor of forage quality as measured by nitrogen or crude protein concentration.

\section{Literature Cited}

Benedetti, R. and P. Rossini. 1993. On the use of NDVI profiles as a tool for agricultural statistics: The case study of wheat yield estimate and forecast in Emilia Romagna. Remote Sens. Environ. 45:311-326.
Box, E.O., B.N. Holben, and V. Kalio. 1989 Accuracy of the AVHRR Vegetation Index as a predictor of biomass, primary production and net $\mathrm{CO}_{2}$ flux. Vegetatio 80:71-89

Caprio, J.M., D.I. Cooksey, J.S. Jacobsen, G.A. Nielsen, and R.R. Roche. 1994. MAPS Atlas Version 5.0: A land and climate information system EB 125, Montana agricultural potentials system. Montana State Univ., Bozeman, Mont.

Carneggie, D.M, B.J. Schrumpf, and D.A. Mouat. 1983. Rangeland Applications. p. 2329-2359. In: Manual of Remote Sensing $\left(2^{\text {nd }}\right.$ ed.) Vol. II, R.N. Colwell (ed.), Amer. Soc. of Photogrammetry, Falls Church, Virg.

Colwell, J.E. 1974. Vegetation canopy reflectance. Remote Sens. Environ. 3:175-183.

Eidenshink, J.C. 1992. The 1990 conterminous U.S. AVHRR data set. Photogrammetric Eng. Remote Sens. 58:808-813.

Gutman, G.G. 1991. Vegetation indices from AVHRR: An update and future prospects. Remote Sens. Environ. 35:121-136.

Holben, B.N. 1986. Characteristics of maximumvalue composite images from temporal AVHRR data. Int. J. Remote Sens. 7:1417-1434.

Justice, C.O. and P.H.Y Hiernaux. 1986. Monitoring the grasslands of the Sahel using NOAA AVHRR data: Niger 1983. Int. J. Remote Sens. 7:1475-1497.

Kennedy, P. 1989. Monitoring the vegetation of Tunisian grazing lands using the normalized difference vegetation index. Ambio 18:119-123.

Kremer, R.G. and S.W. Running. 1993. Community type differentiation using NOAA/AVHRR data within a sagebrushsteppe ecosystem. Remote Sens. Environ. 46: 311-318

Merrill, E.H., M.K. Bramble-Brodahl, R.W. Marrs, and M.S. Boyce. 1993. Estimation of green herbaceous phytomass from Landsat MSS data in Yellowstone National Park. J. Range Manage. 46:151-157.

Mueggler, W.F. and W.L. Stewart. 1980. Grassland and shrubland habitat types of western Montana. USDA Forest Serv., Gen. Tech. Rep. Int-66, Washington, D.C.

Plummer, S.E. 1988. Exploring the relationships between leaf nitrogen content, biomass and near-infrared/red reflectance ratio. Int. J. Remote Sens. 9:177-183.

Richardson, A.J. and J.H. Everitt. 1992. Using spectral vegetation indices to estimate rangeland productivity. Geocarto Int. 7: 63-69.

Richardson, A.J., J.H. Everitt, and H.W. Gausman. 1983. Radiometric estimation of biomass and nitrogen content of Alicia grass. Remote Sens. Environ. 13:179-184.

SAS. 1985. SAS user's guide: Statistics. SAS Inst., Inc. Cary, N.C.

Senft, R.L., L.R. Rittenhouse, and R.B. Woodmansee. 1985. Factors influencing patterns of cattle grazing behavior on shortgrass steppe. J. Range Manage. 38: 82-87.

Smith, P., S. Kalluri, S. Prince, and $\mathbf{R}$. DeFries. 1997. The NOAA/NASA Pathfinder AVHRR 8-KM Land Data Set. Photogrammetric Eng. Remote Sens. 63:12-31. 
Steel, R.G.D. and J.H. Torrie. 1980 . Principles and procedures of statistics: A biometrical approach, $2^{\text {nd }}$ Ed. McGraw-Hill Book Co. New York, N.Y..

Tappan, G.G., D.J. Tyler, M.E. Wehde, and D.G. Moore. 1992. Monitoring rangeland dynamics in Senegal with Advanced Very High Resolution Radiometer data. Geocarto Int. 1:87-98.

Timm, N.H. and T.A. Mieczkowski. 1997. Univariate and multivariate general models: theory and applications using SAS software. SAS Institute Inc, Cary, N.C.

Townshend, J.R.G. and C.O. Justice. 1986. Analysis of the dynamics of African vegetation using the normalized difference vegetation index. Int. J. Remote Sens. 7 1435-1445.
Tucker, C.J. 1979. Red and photographic infrared linear combinations for monitoring vegetation. Remote Sens. Environ. 8:127-150.

Tucker, C.J. and C.L Vanparet. 1985. Satellite remote sensing of total herbaceous biomass in the Senegalese Sahel: 1980-1984. Remote Sens. Environ. 17:233-249.

Tucker, C.J., C. Vanparet, E. Boerwinkel, and A. Gaston. 1983. Satellite remote sensing of total dry matter production in the Senegalese Sahel. Remote Sens. Environ. 13:461-474.

Tueller, P.T. 1989. Remote sensing technology for rangeland management applications. J. Range Manage. 42:442-453.

Vallentine, J.F. 1990. Grazing management. Academic Press, San Diego, Calif.
Wessman, C.A., D.S. Schimel, S. Archer, C.A. Bateson, B.H. Braswell, D.S. Ojima, and W.J. Parton. 1995. New technologies for remote sensing of ecosystem change in rangelands, p. 139-141. In: N. E. West (ed.), Proc. Fifth Int. Rangeland Congress Soc. Range Manage. Denver, Colo.

Wiegand, C.L. and A.J. Richardson. 1990. Use of spectral vegetation indices to infer leaf area, evapotranspiration, and yield: I. Rationale. Agron. J. 82:623-629.

Wylie, B.K., J.A. Harrington, R.D. Pieper, and I. Denda. 1992. A satellite-based range assessment system for the Sahel of Africa. Geocarta Int. 1:79-85.

Wylie, B.K., I. Denda, R.D. Peiper, J.A. Harrington, B.C. Reed, and G.M. Southward. 1995. Satellite-based herbaceous biomass estimates in the pastoral zone of Niger. J. Range Manage. 48:159-164.

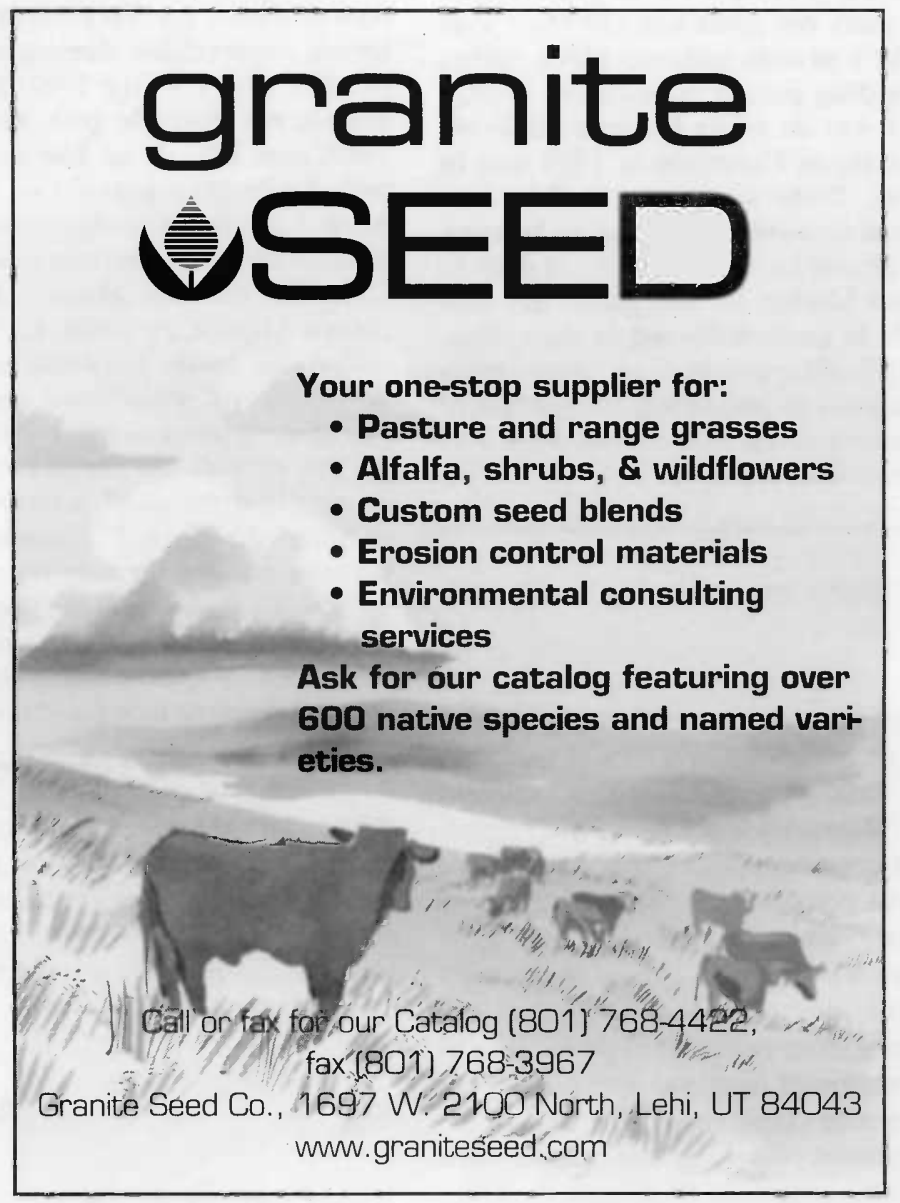

